Arab World English Journal (AWEJ) Special Issue on Covid 19 Challenges April 2021 DOI: https://dx.doi.org/10.24093/awej/covid.5

Pp.68-79

\title{
The Use of Hypermedia Technologies in Higher Education Institutions during Covid Lockdown
}

\author{
Olena Koliasa \\ Department of Germanic Languages and Translation Studies \\ Institute of Foreign Languages, Drohobych Ivan Franko State Pedagogical University \\ Drohobych, Ukraine \\ Corresponding Author: olenakoliasa@gmail.com
}

Iryna Lelet

Department of Philology, Odesa National Maritime University, Odesa, Ukraine

Valeriia Serebriakova

Department of Philology, Odesa National Maritime University, Odesa, Ukraine

Svitlana Yukhymets

Department of Philology, Odesa National Maritime University, Odesa, Ukraine

Recived: $2 / 23 / 2021$

Accepted: $3 / 24 / 2021$

Published: 4/26/2021

\section{Abstract}

The World Wide Web continuously provides rapid access to information, and numerous information resources, virtually unlimited. The convenience and interactivity of its usage encourage people to turn to it in the educational process rather often while teaching or studying unfamiliar topics. Hypertext resources of different kinds have become a virtual educational environment. They offer new opportunities for structuring, presenting, adapting, and integrating contemporary learning materials. Besides, hypermedia technologies have made a considerable breakthrough in the educational process, particularly in selfeducation, combining hitherto incompatible elements. The article focuses on practical experience in the introduction of hypertext in the educational process of higher education institutions in general and during pandemic periods, in particular, the world faces nowadays. In the course of the research, it was emphasized that such technologies are pretty significant in implementing distance learning. Hypermedia technologies create especially suitable conditions for the independent acquisition and quality assimilation of the necessary information, which can be easily integrated into the educational process. The provided analysis of the implementation of e-learning materials based on hypertext and multimedia tools made it possible to point out the advantages and disadvantages of the described technologies (compared to traditional usage of printed textbooks), thus identifying their didactic potential. They became especially of great importance during the coronavirus lockdown.

Keywords: covid lockdown, e-learning materials, higher education, hypermedia educational technologies, hypertext

Cite as: Koliasa, O., Lelet, I.,Serebriakova, V.,\& Yukhymets,S. (2021). The Use of Hypermedia Technologies in Higher Education Institutions during Covid Lockdown. Arab World English Journal (AWEJ) Special Issue on Covid 19 Challenges (1) 68-79.DOI:https://dx.doi.org/10.24093/awej/covid.5 
Arab World English Journal (AWEJ) Special Issue on Covid 19 Challenges April 2021

\section{Introduction}

Informatization and computerization are phenomena inherent in all spheres of modern society. Information and Communication Technologies (ICT) became an integral part of any Higher Education Institutions (HEIs). The e-learning environment is a system that provides students with a new tool for the formation of essential competencies and professional development of modern specialists (Bokalo, 2012).

Polat (1999) defines the e-learning environment as a combination of conditions that provide learning. The primary function of the e-learning environment is to organize convenient conditions for the independent acquisition and quality assimilation of the necessary information used in the learning process. Other but no less essential functions are methodological, communicational, motivational, and evolutional for successful implementation of the abovementioned functions of the e-learning environment into the Ukrainian educational system in training specialists during the coronavirus lockdown, that offer mutual integration of hypermedia technologies into the current educational process in HEIs.

The problem of processing a large amount of information has long been connected with the purpose of optimization of the educational process. Carley (2014) identified the essential principles of hypermedia technologies, among them flexibility and adaptability of the lessons (students can start and complete their tasks at any convenient time); availability of different resources (unlimited number of students can use the same sources of information); minimization of efforts and time (students can send their homework online, saving time and media, etc.), joint work of students through chats, forums, team projects, self-assessment, and self-control.

While organizing the educational process using hypermedia technologies, it is necessary to consider the pedagogical suitability principle of the information and communication methods in contemporary teaching. Most teachers and scholars (Reeeves, 1998; Babelyuk et al., 2020) concluded that the feasibility of computerization is determined by the level of achievement of pedagogical, methodological, and economic efficiency compared to traditional teaching aids. It means that any teacher, who intends to implement modern ICT in their discipline classes, must, firstly, know the mechanism of their application. Secondly, have a sufficient and clear methodological basis for such integration. Thirdly, if it is necessary, to change, and adapt existing methods, taking into account the specifics of their training course. As a result, such educational technologies intensify the individualization of teaching, change the nature of the interaction between students and teachers, turning them into partners in the process of searching and transforming information. It became crucial and valued during coronavirus lockdowns the world faces nowadays.

Therefore, the introduction of hypertext in the educational process of HEIs should be aimed at training qualified specialists of the appropriate professional level, who are competitive, competent, mobile, able to meet international professional standards, highly motivated, ready for continuous professional development, that's in other words, for long-life learning.

The objectives of the research is to highlight the advantages and disadvantages of using hypermedia programs in the educational process in HEIs and the possibility of their integration. 
Arab World English Journal (AWEJ) Special Issue on Covid 19 Challenges April 2021

\section{Literature Review}

The current state of hypertext studies, according to Dedova, is characterized by the fact that despite the great interest in "hypertext topics," publications in which the authors analyze specific features of hypertexts are virtually absent. The researcher names two main reasons for the described situation. The first reason is the inefficiency of the theoretical basis of such researches, as hypertext being a specific, innovative object of analysis, the product of a new field of written communication, cannot be studied based on traditional textology theories. The second reason is that the term "hypertext" has many theoretical and practical projections on various fields of modern scientific knowledge, among them computer science, sociology, linguistics, literature, pedagogy, etc. (Dedova, 2008). It is necessary to resort to essential historical information and the preconditions for the emergence of the hypertext idea to understand the essence of this phenomenon.

In the field of cybernetics and computer technology, the issues of hypermedia and hypertext systems were dealt with by Epshtein (2016), who developed the concepts of "hypertext and "hypertext systems." On the contrary, Monakhov (2007) and Kahn (1993) considered the negative consequences of working in a hypertext virtual environment.

Hypertext and hypermedia technologies are used in educational technology for the following reasons: hypermedia non-linear access to vast amounts of information (Nielson, 1997); users can explore a text in depth (Collier, 1987); interaction with the instructional material can be self-paced (Barrett, 1988); hypermedia catches attention and engages the users (Jonassen, 1990); hypermedia represents a natural form of representation simulating the work of human mind (Delany\&Gilbert, 1991; Koliasa, 2016).

The purpose of the article is to highlight the advantages and disadvantages of hypermedia technologies in the educational process of HEIs.

\section{Methods}

The research uses the notions of hypertext, hypermedia system, and technologies as an effective tool for supplying learners with all necessary information. With the help of linguistic and extra-linguistic methods, hypermedia categories were defined those that include macro literary systems, which center on the integration and ready accessibility of large volumes of information; problem exploration systems, they are designed to allow the interactive manipulation of data; systems for structured reading/ browsing/reference; and, finally, systems that might have been applied to a specific application but whose real purpose in construction had been the experimental investigation of hypertext technology itself. The educational implications of hypertext rest on a mixture of these three underlying tendencies.

The considered possibilities of hypertext allow addressing the question of structuring of educational material via hypertext technology. It means that it is necessary to identify a specific set of educational material elements and establish links between them based on hypertext technology.

To structure educational information in hypertext for the formation of knowledge of English for professional purposes, it is essential to follow the following algorithm, which includes compiling a dictionary of terms; identifying objects and concepts; identifying the relationship between concepts; detailing. 
Arab World English Journal (AWEJ) Special Issue on Covid 19 Challenges April 2021

\section{Data Collection Procedure}

There are more than 100 different types of hypermedia systems that are designed by people for different needs. The hypermedia system was proposed by Bush when he worked as a scientific adviser to Roosevelt in 1945. Already in those days, he foresaw the problem of disseminating information and developed a mechanical recorder, which he called Memex for his own needs. Its function was "to store books, notes, conversations, which were organized in such a way that could be quickly accessed" (Bush, 1945, p. 4). In other words, Memex was a unique recorder, "(...) in which individual stores his books, records, and communications, and which is mechanized, so that it may be consulted with exceeding speed and flexibility" (Bush, 1945, p. 5).

The device was more than just an ordinary storage medium. Memex was based on association, with the help of which all facts, concepts, and ideas were connected in memory, and that any piece of information organized on the ad hoc principle that can act as stimulus or trigger ("trigger mechanism") to remember another (Koliasa, 2016).

Besides developing this device, Bush sought the best ways to store and search for information, combining the principle of similarity with the mind activities. However, the given amount of information a person needs, taking into account what we know about unstable associative relationships (e.g., Howe, 1980), it was unlikely that such a principle could be the basis of a hypermedia system.

While Bush sought to develop systems based on cognitive equivalence, in the early 1960s, Doug Engelbart developed his hypertext concept, emphasizing the strength of human intelligence (Engelbart, 1963), by naming the system Augment. Engelbart's first implementation was the NLS (On-Line System), which was designed to serve the work needs of his human intelligence research center at the Stanford Research Institute. It was a simple computer environment that contained all the documents, notes, notes, reports, etc. Thus, the On-Line System can be considered one of the first attempts to provide a hypertext environment in which collaboration could take place using a computer.

Conceptualizing technology like this, Engelbart saw hypertext as a form of a cognitive artifact that enhances human capabilities and offers the potential to achieve productivity level in information tasks that would be difficult or impossible to achieve without it.

The introduction of the term "hypertext" is attributed to Nelson (1997). He called his dream system Xanadu - "documentation," which connects all the world literature, namely, "a universal instant network of hypertext publications" (pp. 84-100).

There was no need to write anything twice in Xanadu. The document consists of the original or native bytes, which are inclusions, and provides transfer and inclusion of one form in another. However, an essential aspect of Xanadu was that the transaction was virtual. Each document contained a reference to the original structure and not to copies of its parts.

Nelson's definition of hypertext is as follows: "a combination of natural language text with the computer's capacities for interactive, branching, or dynamic display (...) of a non-linear text, which cannot be printed conveniently on a conventional page" (Nelson, 1997, pp. 94-100). 


\section{Arab World English Journal (AWEJ) Special Issue on Covid 19 Challenges April 2021}

It is necessary to highlight its leading characteristics to understand the essential difference between conventional text and hypertext.

Hypertext is the representation of information as linked nodes, in which the reader navigates nonlinearly. It also allows the possibility of a plurality of authors, the blurring of the functions of the author and the reader, the expansion of work with blurred boundaries, and the multiplicity of ways of reading (Vizel, 2016). As far as we can see from this definition, there are three essential aspects of hypertext: the dispersion of its structure (information can be provided in the form of small fragments-nests, and "entrance" to this structure can be from any link), nonlinearity (the reader is free to choose the reading path while creating one's text), and diversity and multimedia (i.e., the use of all means to influence the reader, which is technically possible only within this system).

When considering the concepts of text and hypertext in general, the following differences can be found, among them the linearity of the text vs. nonlinearity of hypertext; completeness of traditional text vs. infinity, incompleteness, the openness of hypertext; exact authorship of the text vs. lack of authorship (in the conventional sense) in hypertext; removal (using hypertext) of opposition between the author and the reader; subjectivity, the one-sidedness of plain text vs. objectivity, the versatility of hypertext; homogeneity of plain text vs. heterogeneity of hypertext (Baranov, 1997).

Hypermedia is an extension of hypertext that allows the user to create a linked database of materials, including text, static graphics, animated graphics, video, sound, music, etc. The difference between hypertext and hypermedia is that a hypertext system allows users to combine only textual information blocks, whereas hypermedia provides such capability between heterogeneous blocks of information created by different tools or programs.

Despite the shortcomings of paper media, their use continues and is quite common in the last seven centuries. Of course, it is quite convenient to keep books, magazines, documents at hand and then re-read and work with them. However, if you want to combine other media, such as a video, it becomes impossible to store audio and immediately process heterogeneous information formats in one database or platform.

Hypertext systems significantly differ from printed ones, including structure, organization, and functionality. They are distinguished by their advantages, which are quite obvious. In the hypertext database, we can change the structure quickly or move from one fragment to another. One can create, edit, and reorganize pieces according to their needs and interests. A user can track the most minor piece of information in an extensive database. One can also combine information using associative and intuitive connections, regardless of location.

\section{Findings}

For more than 40 years, all that has been offered to teachers to carry out their activities are technological "solutions" (from program text to modern computers), which are supposed to increase their efficiency. Courses such as Computer Based Learning (CBL) or Computer-Aided Instruction (CAI) are designed to provide some of the up-to-date functions of a teacher. 
Arab World English Journal (AWEJ) Special Issue on Covid 19 Challenges April 2021

Since the introduction of hypertext into the learning process, it has gained both critics and supporters. Critics (Duchastel, Velay) insisted that hypertext reduces teaching to optimize the presentation of the material.

The perceived advantages of hypertext as an educational environment are usually attributed to its non-linear properties. It often contrasts with the supposed linearity of traditional texts, as in the statement: "Unlike [hypertext], most standard text documents are built for reading linearly, from the starting page to the end" (Berg, 1991, p. 118). Unfortunately, there are currently few studies that objectively and with the descriptions of some results evaluate hypertext in the educational environment -empirical testing of real users who interact with hypertext.

One of the first attempts to assess the potential of hypertext in the learning process was a report made by Beamen et al. (1987), which described practical results of using the Intermedia hypernet system in two courses at Brown University, namely, in the course of English literature, and biology. Teams of sociologists observed the courses before the introduction of hypertext and when using hypertext materials. Teachers and students were interviewed several times during the experiment. Besides, a group of students was asked to keep diaries of their activities during their studies. The use of a specially created computer laboratory was monitored by both students and teachers.

At first glance, the preliminary results of the introduction of hypertext were positive. The developers reported a positive correlation between the use of hypermedia and high scores. However, they also reported an unexpected finding that the improvements might not have been related to the introduction of hypertext as such but rather to a factor related to its implementation.

Beeman's research is an excellent illustration of the difficulties involved in assessing the effect of implementing not only hypertext but also any new, unknown educational technique into the educational context. Moreover, Beeman's most interesting finding was that the significant performance indicators observed in the process of implementing Intermedia were more pronounced among people who participated in its implementation than among students who used the system, apparently confirming the statement that "the best way to learn something, is to teach!" (Beeman, 1987, p. 77).

Hammond \& Allinson (1989) believe that hypertext can serve as a basis for a research system of learning. Still, it is insufficient and must be supplemented by more targeted mechanisms of guidance and access.

Stanton \& Stammers (1990) suggest that a non-linear organization may be more effective than a linear one and find reasons to support his statement. First, it will enable different levels of prior knowledge. Second, it encourages research. Third, it allows subjects to see the task and adapt the material to their learning style. 
Arab World English Journal (AWEJ) Special Issue on Covid 19 Challenges April 2021

\section{Discussion}

It can be argued that the hypertext environment provides more control over students, and therefore has advantages over traditional paper materials. However, this makes it possible to come to two equally plausible interpretations: 1) greater control over the user access to the hypertext content through links provided by the author/ developer, or 2) greater control by the user because they are free to follow their own choices, an option, that is more complex, than printed text.

The concept of control is essential in the educational process, but it remains unclear whether hypertext gives the student more power than traditional media. Duchastel (1988) argues that computers facilitate interaction through a manipulative learning style, where the student responds to the information provided by using the mouse to select items and move through the information space, but does not make the process more "active" than turning book pages, emphasizing excerpts, and writing notes in the margins.

There is, however, some doubt as to whether all these process-oriented educational aspects of hypertext systems are necessarily "good" in any learning situation. There is much evidence that students, who are free to choose their strategies, do not always choose wisely" (Duchastel, 1988, p. 322). This statement reflects previous assumptions that most students cannot set and study learning goals on their own. On the other hand, access to a broad and rich interconnected hypermedia database may be of genuine interest to, for example, a researcher trying to identify common factors that have influenced the diversity of human activity. As Whalley (1990) points out, "a hypertext reader can easily fly between trees but still can not perceive the shape of a tree better than before" (pp. 61-67).

Jonassen, who is one of the most prominent scholars in the field of hypertext researches and learning, reported on a series of studies that sought to evaluate hypertext in terms of acquiring structural knowledge. Jonassen concluded that his results call into question "the ability of students to engage in meaningful learning, rather than to search for information from hypertext, especially in the context of the learning environment" (Jonassen et al., 1990, p. 165).

Not being a "natural" learning environment that somehow reflects semantic memory, Jonassen suggests that "fair assessment can only occur in hypertext literacy, while students have acquired a useful set of strategies for navigating, and integrating information from hypertext" (Jonassen et al., 1990, p. 165).

Marchionini \& Schneiderman (1988) suggested that hypertext is more suitable for viewing than for search. Based on this assumption, Jones (1989) hypothesized that more random learning would occur when reviewing tasks than in a work that requires the use of a reference. Jones (1989) argued that hyperlinked links were built-in menus and that the context provided by the site should encourage ideas to be connected at any end of the link. In other words, a semantic connection is likely to be found, and only then, a mental operation aimed at memorization and learning will take place.

In general, these studies reflect the current problems that arise when using hypertext in learning, namely difficulties in controlled experiments, finding tasks, describing the educational 


\section{Arab World English Journal (AWEJ) Special Issue on Covid 19 Challenges April 2021}

process, not to mention assessment - learning outcomes. Marchionini (1990) sums it up that "a significant problem in evaluating highly interactive systems is the evaluation of both, the quality of interaction, and learning outcomes. Evaluations of learning based on hypermedia should relate to the learning process and learning outcomes" (p. 206).

Given all the advantages listed above, we may sum it up that hypertext is an integral tool of learning in today's globalization of the educational system in general. In the hypertext environment, there is no difference between an author and a reader, and a student, and a teacher. Everyone is equal.

Films, audio-visual materials, presentations, and other teaching materials have always been helped in the learning process. But not one of them has replaced conventional teaching aids. Modern teaching aids have changed the role of a teacher from instructor to assistant. The use of media and computers has revolutionized the teaching process in schools, colleges, and universities. Teachers began to develop their lessons using video and computer-based instructional programs that allow students to listen, watch and work with their course materials. A compelling advantage of using hypermedia to study a course is that the student can return to the material, which raises some doubts about how many times he or she needs it.

In the '80s, new training programs were developed. Among expert systems are Interactive Video Disc (IVD), Computer-Aided Learning (CAL), Computer Based Training (CBT), Multimedia, and hypertext (MHT).

Multimedia and hypertext programs have become the most used in the learning process due to their ability to combine disparate fragments in a non-linear way, and to use them efficiently while storing a large amount of information. Hypertext presents tremendous potential and flexibility in the process of delivering educational material. Besides, students can change the sequence of information in the learning process according to their wishes or understanding. Studies of hypertext in the learning process have shown critical and logical thinking skills in building relationships between pieces of information (Landow\& Delany, 1991).

Hypertext should also be used at the stage of revision and self-study of already learned material. It combines a lot of disparate information, but not at the stage of introducing new material and explaining the essential information.

In dealing with hypertext, students develop the ability to find different ways to solve problems and explore issues compared to the traditional way of learning.

Advantages of using hypertext as a learning tool are the following:

1) optimal freedom of choice;

2) provides links between fragments of information placed randomly;

3) the ability to highlight, comments, and mark;

4) the only form that does not require differentiation by age, style, or field;

5) the ability to find additional information without leaving the screen;

6) the ability to combine different forms of presentation of material (graphics, video, sound, text, etc.); 


\section{Arab World English Journal (AWEJ) Special Issue on Covid 19 Challenges April 2021}

7) the ability to apply individual instructions;

8) to work in groups, having the opportunity to exchange views, information.

The impact of hypertext on the learning process can be briefly presented by such essential aspects as the replacement of traditional tools with dynamic visual media; special programs for developers of hypertext courses in graphics, programming, psychology, and cognitive linguistics; the development of analytical thinking, and professional skills of students.

Among many advantages that hypertext has as, no doubt, a helpful learning tool, it should be noted its disadvantages. Hypertext itself often takes the form of broken fragments. If the connections are not logical, it becomes ineffective. The success of the presentation and processing of the material depends on the developer of the hypertext. There is a high probability of getting lost in this web because of fragmentation.

Although the idea of creating hypertext came much earlier than the creation of the computer, it was not popularized because people still do not understand the essence of hypertext and its effectiveness in everyday usage and in the system of education in particular.

Despite some shortcomings, hypertext has enormous potential over other means by which information can be presented effectively. The main task now is to develop vocabulary, syntax, and structure to achieve maximum benefit. Its effectiveness as a learning tool has already been proven; students improve creativity, mobility, determination, ability to evaluate, synthesize information, increase self-esteem. Hypertext program developers are working to address the shortcomings of the systems. If these systems overcome the problem of incompatibility, the mass introduction of hypermedia in the process of learning and self-education is inevitable.

As to the practical experience of using hypertext technology and the description of educational hypertext for ESL students, which includes the following stages:

1) The basic concepts on the topic are revealed and systematized, the thesaurus in the form of the structural-hierarchical scheme is made. Thus, we defined the general structure of hypertext.

2) The formation of semantic nodes containing text, video, graphics, an alphabetical index, and a system of hyperlinks are formed.

The principle of constructing hyperlinks based on two types of systematization of information: lexical-grammatical/semantic and system of sub-objects.

The creation and development of e-learning resources are associated with the need to improve significantly the quality of teaching subjects in higher education institutions during the pandemic periods. To achieve this goal, the software product must have academic completeness, didactic value, and effectiveness (Babelyuk et al., 2020). Electronic textbooks and manuals, based on hypertext technology, provide many advantages: the ability to structure and organize educational information by external "unloading" of the text. Representation of information in a non-linear way contributes to implementing the principle of visualization in that the link allows you to learn different concepts, objects with the help of video materials and graphics. The visualization of information increases the interest of students and stimulates them to learn new material. 
Arab World English Journal (AWEJ) Special Issue on Covid 19 Challenges April 2021

\section{Conclusion}

Analyzing the results of the introduction of hypermedia technologies in the educational process, we concluded that the main advantages of this technology are as follows: easy usage the ability to follow links in different directions, active state of students during the educational process, interactive communication with the electronic system, i.e., learning environment, variety of forms and modes of behavior, modularity of construction - it is possible to refer to one text segment from different blocks, which increases the information saturation and reduces the amount of duplicated information, compatibility - several authors can work on one document, the flexibility of computer learning, ability to regulate, and control the speed and intensity of training, workload, optimization, and intensity of information, as well as update information. It should be noted that the use of electronic educational resources developed based on hypertext increases the potential of the teacher, offering more freedom for his creative search for new teaching methods and technologies that involve students in the creative process. Also, their use increases the students' motivation, allows combining classroom, and extracurricular activities on an interactive basis. It improves the quality of graduate training.

The practicality of creating, and maintaining an educational environment in HEIs, especially during the coronavirus lockdown, is determined by several factors: increasing the speed of information and knowledge transfer; the need for dynamic adaptation of students to the environment, and social changes taking place in it; the need to reform the educational system in accordance to the requirements of the digital information society (increasing productivity, transparency, and flexibility of educational processes, learning according to needs, and abilities). Electronic educational resources and educational environments created on their basis have significant potential for improving the quality of training of future professionals. We see the prospects for further research in substantiating some other new sufficient organizational and pedagogical conditions of students studying in the educational environment of HEIs.

In conclusion, it should be emphasized that introduction into the educational process of electronic educational resources developed on hypertext technology, including electronic textbooks, is not an educational panacea but only a new tool to modernize and increase the efficiency of the educational process. As Heick (2019) once said that there is now more information available to any student with a smartphone than the whole empire had three thousand years ago.

About the Author:

Olena Koliasa, PhD, an Associate Professor of Drohobych Ivan Franko State Pedagogical University. Now is currently working on problems of Cognitive Linguistics and Postmodern Poetics, Stylistics, Text Interpretation.

https://orcid.org/0000-0001-5301-480X

Iryna Lelet, $\mathrm{PhD}$, Assistant Professor, Odesa National Maritime University; Ukraine, Odesa. Graduated with honours from Odesa State University named after I. I. Mechnikov. Now is working on problems of technical terminology translation and innovative methods of teaching English for specific purposes in higher educational institutions.

https://orcid.org/0000-0002-0865-9358 
Arab World English Journal (AWEJ) Special Issue on Covid 19 Challenges April 2021

Valeriia Serebriakova, $\mathrm{PhD}$, Assistant Professor, Odesa National Maritime University; Ukraine, Odessa. Received the master degree in Language and Literature ( English) at Odessa State University named after I.I.Mechnikov. Supported the thesis "Conceptualization of the Poetonymic Sphere in S.Meyer's Cycle of Novels - "Twilight".

https://orcid.org/0000-0002-2852-9358

Svitlana Yukhymets, PhD, Professional qualification: Philologist-Translator into the English Language, University Teacher of Theory and Practice of Translating. Her research interests cover a range of linguistic problems, many of which fall within the scope of translation as well as foreign language teaching methods.

https://orcid.org/0000-0003-3350-7310

\section{References}

Babelyuk, O., Koliasa, O., Kushlyk O, \&Smaglii V. (2020). Using Distance EdTech for Remote Foreign Language Teaching During the COVID-19 Lockdown in Ukraine (November 23, 2020). Arab World English Journal (AWEJ) Special Issue on the English Language in Ukrainian Context, November 2020, Available at https://www.awej.org/images/AllIssues/Specialissues/SpecialIssueonheEnglishLanguage nraqiContext2020/SpecialIssueonheEnglishLanguageonUkraineContext2020/1.pdf $\quad$ or http://dx.doi.org/10.2139/ssrn.3735588

Bakalo, D. I., \& Shishkovskaya, J. V. (2012). Informacionno obuchajushhaja sreda vuza v kontekste Internet obrazovanija [Information learning environment of the educational institution in the context of Internet education], TSPU Bulletin, 4(119), 48-54.

Baranov, O. (1997). Gipertekstovaya subkultura. [Hypertext subculture]. Znamya,7, 202-205.

Barret, E. (1988). Text, context \& hypertext. Cambridge, MA: MIT Press.

Beeman, W. O. et al. (1987). Intermedia - a case study of innovation in higher education. Province, RI: Office of the orofram analysis. IRIS: Brown University.

Berg, S. V. D., \&Watt, J. H. (1991). Effects of educational setting on student responses to structured hypertext, Journal of Computer-Based Instruction, 18(4), 118-124.

Bush, V. (1945). As We May Think. Available at: http://www.w3.org/History/1945/vbush/vbushall.shtml.

Carley, H. (2014). Going green: The Paperless Classroom Global Issues in Language Education. Newsletter Issue, 91, 10-13.

Collier, G. (1987). Thoth-II. Hypertext with explicit semantics. In Proceedings of Hypertext '87 (pp. 269-289). Chapel Hill: University of North Carolina.

Dalany, P. \& Gilbert, S. (1991). Hypercard stacks for Fielding's Joseph Andrews: Issues of design and content. In D. Delaney \& G. Lanrow (Eds.), Hypermedia \& literary studies (pp. 287-298). Cambridge, MA: MIT Press.

Dedova, O.V. (2008). Teoriya giperteksta $i$ gipertekstovye praktiki $v$ Runete [The theory of hypertext and hypertext practice in the RuNet]. Moskva: MAKS Press.

Duchastel, P. (1988). Display and interaction features of instructional texts and computers, British Journal of Educational Technology, 19(1), 58-65.

Engelbart, D. C. (1963). A conceptual framework for the augmentation of man's intellect, Vistas in Information Handling (pp. 1-29). London: Cleaver-Hume. 
Arab World English Journal (AWEJ) Special Issue on Covid 19 Challenges April 2021

Epshtein, V. L. (2016). Vvedenie $v$ gipertekst $i$ gipertekstovye sistemy [The introduction to hypertext and hypertext systems]. Available at: http://www.ipu.rssi.ru/publ/epstn.htm

Hammond, N. (1989). Hypermedia and learning: who guides whom? In H. Maurer, ed. Computer assisted learning (pp. 167-81). Berlin, Germany: Springer.

Hammond, N. \& Allinson, L. (1989). The travel metaphor as design principle and training aid for navigating around complex systems. In D. Diaper \& R. Winder, eds. People and computers 111. Cambridge, England: Cambridge University Press.

Heick, T. (2019). How 21st Century Thinking is Just Different. Available at: http://www.teachthought.com/learning/how21st-century-thinking-is-different/

Howe, M. J. A. (1980). The Psychology of Human Learning. New York: Harper and Row.

Jonassen, D. H., et al. (1990). Problems and issues in designing hypertext/ hypermedia for learning, In D. H. Jonassen, \& H. Mandl, (eds.), Designing Hypermedia for Learning (pp. 3-25). Heidelberg: Springer-Verlag.

Jones, T. (1989). Incidental learning during information retrieval: a hypertext experiment. In $\mathrm{H}$. Maurer, ed. Computer assisted learning (pp. 235-51). Berlin, Germany: Springer.

Kahn, P. (1993). The Pleasures of Possibility: What is Disorientation in Hypertext? Journal of Computing in Higher Education, 4(2), 57-78.

Koliasa, O.V. (2016). Adhocratychne poetychne myslennya yak kognityvno-semantychnyi mehanizm tvorenia igrovogo absurdu $\mathrm{v}$ postmodernistskomu fantazijnomu opovidanni. [Ad hoc poetic thinking as cognitive-semantic mechanism of creation of ludic absurd in postmodern fantasy story]. Molodyi Vchenyi, 2(29), 383-387.

Landow, G.\& Delany, P. (1991). Hypermedia and Literary Studies, Cambridge, MA: MIT Press. Marchionini, G. (1990). Evaluating hypermedia-based learning. In D. H. Jonassen, \& H. Mandl, (eds.), Designing Hypermedia for Learning (pp. 355-373). Heidelberg: Springer-Verlag.

Marchionini \& Shneiderman, B. (1988). Finding facts versus browsing knowledge in hypertext systems. IEEE Computer, Jan., 70-80.

Monahov, K. (2007). Gipertekst kak bolezn [Hypertext as a malady]. Available at: http://www.monakhov.ru/2007/06/13/gipertekst-kak-bolezn/.

Nelson, Th. H. (1997). Back To the Future: Hypertext the Way It Used To Be. Available at: http://xanadu.com/XanaduSpace/btf.htm.

Polat, E. S., \& Buharkina, M. Yu. (1999). Sovremennye pedagogicheskie i informacionnye tehnologii v sisteme obrazovanija [Modern pedagogical and information technologies in educational system]. Moscow: Akademiya Publishers.

Reeves, T. C. (1998). Evaluating what really matters in computer-based education. Available at: http://eduworks.com/Documents/Workshops/EdMedia1998/docs/reeves.html

Stanton, N.A. \& Stammers, R.B. (1990). Learning styles in a non-linear training environment. In R. McAleese \& C. Green, eds. Hypertext: state of the art (pp. 114-20). Oxford, England: Intellect.

Vizel, M. (2016). Giperteksty po tu i etu storonu ekrana, [Hypertexts before and behind the screen], Available at: http://www.litera.ru/slova/viesel/visel-ht.html.

Whalley, P. (1990). Models of hypertext structure and learning. In D. H. Jonassen, \& H. Mandl, (eds.), Designing Hypermedia for Learning (pp. 83-92). Heidelberg: Springer-Verlag. 